\title{
RNASEL wt Allele
}

National Cancer Institute

\section{Source}

National Cancer Institute. RNASEL wt Allele. NCI Thesaurus. Code C101336.

Human RNASEL wild-type allele is located in the vicinity of $1 \mathrm{q} 25$ and is approximately 16 $\mathrm{kb}$ in length. This allele, which encodes 2-5A-dependent ribonuclease protein, is involved in the antiviral response. Mutation of the gene is associated with prostate cancer hereditary type 1. 